\title{
Harnessing host innate immunity may combat acquired resistance to BRAFi
}

\author{
Thomas Tan ${ }^{1}$, Pradeepa Pangigadde ${ }^{2}$, Francesco Sabbatino ${ }^{3}$, Elvira Favoino ${ }^{3}$, Laura Orgiano ${ }^{1}$, Soldano Ferrone ${ }^{3}$, \\ Ennio Carbone ${ }^{2}$, Francesco Colucci ${ }^{1 *}$ \\ From Melanoma Bridge meeting 2013 \\ Naples, Italy. 5-8 December 2013
}

\section{Background}

Natural Killer (NK) cells are innate immunity lymphocytes that spontaneously recognise and kill melanoma cells [1]. Dacarbazine synergises with host immunity by inducing stress signals (NKG2D-L) that alert NK cells [2]. This provides an example of how cancer therapies and host innate immunity may be combined to improve management of melanoma patients. BRAF inhibitors (BRAFi) are radically changing clinical practice in melanoma treatment because they offer unprecedented survival gains. However, melanoma patients nearly always relapse with drug-resistant disease after 6-12 months into the treatment. While evidence is emerging that BRAFi may modulate host immunity, the effect of BRAFi on the cross talk between NK cells and melanoma cells is unknown.

\section{Material and methods}

BRAF-mutant melanoma cell lines 1520, SK-MEL-37 and Colo38 were cultured for 4 weeks in the presence of $5 \mu \mathrm{M}$ vemurafenib. BRAFi-resistant variants were sequenced to confirm the presence of the $\mathrm{BRAF}^{\mathrm{V} 600 \mathrm{E}}$ mutation and exclude outgrowth of BRAF ${ }^{\mathrm{WT}}$ clones. NK cells were isolated from the blood of healthy donors and activated with IL-2. Melanoma cell killing by NK cells was quantified before and after BRAFi treatment by FACS (CD107 degranulation assay) and/or by chromium release assays. MAPK signalling in melanoma cells was quantified by FACS (phospho-ERK). Expression of HLA class I, TRAIL, PD-1L as well as ligands for NKG2D, NCRs and DNAM-1 on melanoma cells was assessed by FACS. Receptor expression was assessed by FACS on blood NK cells from

* Correspondence: fc287@medschl.cam.ac.uk

${ }^{1}$ School of Clinical Medicine, University of Cambridge, United Kingdom

Full list of author information is available at the end of the article healthy donors or by confocal microscopy in lymph node biopsies of metastatic melanoma patients.

\section{Results}

Melanoma cells that acquired BRAFi resistance through increased MAPK signalling developed also resistance towards NK cell killing. Expression of HLA class I, PD-1L and TRAIL was often elevated in drug-resistant melanoma cells compared to parental melanoma cells, whereas the expression of other NK receptor ligands did not significantly change. PD-1 was found on a subset of NK cells from some melanoma patients and on IL-2 activated NK cells from some healthy donors.

\section{Conclusion}

These data suggest that the PD-1/PD-L1 pathway is an attractive target to restore NK cell activity towards melanoma cells in some patients, thus harnessing host innate immunity to combat acquired BRAFi-resistance.

\footnotetext{
Authors' details

${ }^{1}$ School of Clinical Medicine, University of Cambridge, United Kingdom. ${ }^{2}$ Karolinska Institute, Stockholm, Sweden and Università di Catanzaro Magna Graecia, Italy. ${ }^{3}$ Massachusetts General Hospital, Boston, United States.

Published: 6 May 2014

References

1. $\quad$ Lakshmikanth T, Burke S, Ali TH, Kimpfler S, Ursini F, Ruggeri L, Capanni M, Umansky V, Paschen A, Sucker A, Pende D, Groh V, Biassoni R, Höglund P, Kato M, Shibuya K, Schadendorf D, Anichini A, Ferrone S, Velardi A, Kärre K, Shibuya A, Carbone E, Colucci F: NCRs and DNAM-1 mediate NK cell recognition and lysis of human and mouse melanoma cell lines in vitro and in vivo. J Clin Invest 2009, 119(5):1251-63.

2. Hervieu A, Rébé $C$, Végran F, Chalmin F, Bruchard M, Vabres $P$, Apetoh L, Ghiringhelli F, Mignot G: Dacarbazine-mediated upregulation of NKG2D ligands on tumor cells activates NK and CD8 T cells and restrains melanoma growth. J Invest Dermatol 2013, 133(2):499-508.
} 
doi:10.1186/1479-5876-12-S1-010

Cite this article as: Tan et al: Harnessing host innate immunity may combat acquired resistance to BRAFi. Journal of Translational Medicine 2014 12(Suppl 1):010.

Submit your next manuscript to BioMed Central and take full advantage of:

- Convenient online submission

- Thorough peer review

- No space constraints or color figure charges

- Immediate publication on acceptance

- Inclusion in PubMed, CAS, Scopus and Google Scholar

- Research which is freely available for redistribution

Submit your manuscript at www.biomedcentral.com/submit

C BioMed Central 